\title{
Small hive beetle infestation levels of honey bee colonies correlate with precipitation and forest cover
}

\author{
Kayode Lawrence AkInwande ${ }^{1}$, Peter NeumanN ${ }^{2}$ \\ ${ }^{1}$ Department of Biology, Federal University of Technology, Akure, Nigeria \\ ${ }^{2}$ Institute of Bee Health, Vetsuisse Faculty, University of Bern, 3097, Bern, Switzerland
}

Received 28 November 2017 - Revised 1 March 2018 - Accepted 26 April 2018

\begin{abstract}
Small hive beetles (SHBs) are parasites of social bee colonies endemic to Africa and have become a widely distributed invasive species. Damage to colonies in the new ranges seems to be governed by higher infestation levels, but the factors underlying SHB numbers are poorly understood. Since SHBs pupate in the soil outside of colonies, local temperature and humidity are likely to underlie infestation levels. Here, we conducted a survey in Nigeria of 82 honey bee colonies, Apis mellifera adansonii (26 apiaries, 14 states), in both forest and savannah with a range of temperatures and precipitation. We recorded significantly higher SHB infestation levels in forests compared to savannah. While there was no significant correlation between local temperature and SHB infestation levels, a significant positive correlation was found between local rainfall and SHB numbers in colonies. Under the temperature conditions of the study region, precipitation and a forest cover appear to impact SHB infestation levels of honey bee colonies. Our data suggest that new SHB distribution ranges with both forests and high precipitation will be especially at risk.
\end{abstract}

\section{Aethina tumida / Apis mellifera adansonii / ecosystem / honey bee / parasite / small hive beetle}

\section{INTRODUCTION}

Invasive species are a key component of global environmental change (Dawson et al. 2017), and their detrimental impact can be driven by a range of environmental factors (Nentwig 2007). In order to mitigate biological invasions, it appears crucial to better understand environmental factors fostering the invasion success of individual species. Since factors may interact with each other, studies in the native range seem to be advantageous, because some factors can be excluded, e.g., enemy release (Mitchell and Power 2003; Torchin et al. 2003) and/or higher susceptibility of novel

Corresponding author: K. Akinwande, akinkay20032001@yahoo.com

Manuscript editor: David Tarpy hosts in case of invasive parasitic species (Rosenkranz et al. 2010).

The small hive beetle, Aethina tumida (SHB), has originally been described as a parasite of Western honey bee (Apis mellifera) colonies endemic to sub-Saharan Africa (Lundie 1940; Hepburn and Radloff 1998). Later laboratory studies suggested that it may also reproduce in association with food outside of colonies (e.g., fruits and meat, Ellis et al. 2002; Buchholz et al. 2008). However, respective field surveys did not confirm this finding (Buchholz et al. 2008; Mutinelli et al. 2015; Willcox et al. 2017). It therefore appears as if alternative food sources outside of bee colonies are of minor importance only for SHBs (Willcox et al. 2017). In contrast, SHB infestations of other social bee colonies have repeatedly been shown in the field (Eastern honey bees Apis cerana, bumblebees, and stingless bees; Neumann et al. 2016; Cervancia et al. 2016). There is consensus that SHB can regularly 
be found within honey bee, A. mellifera, nests, where it usually hides at the bottom of cells, in debris on the hive bottom, or in cracks of hive walls (Neumann et al. 2016). In the nests, adult SHBs are fed by honey bee workers (Ellis 2005; Neumann et al. 2015) and both adults and larvae can feed on brood, stored food, dead and live adult bees, and debris (Neumann and Elzen 2004; Spiewok and Neumann 2006; Pirk and Neumann 2013).

In their native range in Africa, SHBs are usually considered to be a minor pest only (Hepburn and Radloff 1998). In sharp contrast, SHBs can cause significant damage to apiculture and may also endanger wild/feral bees in areas, where it has been introduced (Neumann et al. 2016). Weak and strong colonies of European honey bee subspecies can succumb to SHB infestations within one week (Neumann et al. 2012), often resulting in the full structural collapse of the entire nest (Hepburn and Radloff 1998). The underlying reasons for those apparent differences in the impact of SHBs are not fully understood yet and may range from (1) quantitative differences in behaviour between African and European honey bee subspecies (Neumann and Elzen 2004), over (2) the "natural enemy release hypothesis" in which a pest thrives in a new range because of the lack of natural enemies (Mitchell and Power 2003; Torchin et al. 2003) to (3) the role of alternative hosts (reviewed by Neumann et al. 2016; Neumann 2017). However, on the other hand, it is well known from field experience that damage to honey bee colonies positively correlates with SHB infestation levels (Spiewok et al. 2007). In order to mitigate the impact of this invasive species, it is therefore relevant to better understand drivers of population dynamics.

In contrast to other parasites, an integral portion of SHB life history occurs outside of colonies (Neumann et al. 2016). Therefore, these beetles are more exposed to environmental factors compared to other parasites, which spend their life history almost exclusively in the more homeostatic nests of social bees (e.g., ectoparasitic mites Varroa destructor; Rosenkranz et al. 2010). The post-feeding, so-called wandering SHB larvae leave the hives to pupate in the soil (Lundie 1940). Then, warmer ambient temperature and higher soil moisture promote pupation success and also reduce the duration of pupation (Ellis et al. 2004; De Guzman et al. 2009). Honey bee hives located in the shade appear to be more attractive to adult free-flying SHBs (Arbogast et al. 2007, 2009; but see Ellis and Delaplane 2006). Since the tree canopy provides abundant shade, forests may therefore be more attractive for adult SHBs. Forests may also offer more suitable soil for pupation (Ellis et al. 2004), more adequate levels of soil moisture and temperatures (Afolabi et al. 2009), and possibly a higher abundance of wild host nests (e.g., honey bees; Hepburn and Radloff 1998). Forest areas may therefore display higher SHB infestations levels compared to other areas. However, population data for this pest are still scarce at present, especially for the native range of SHBs in Africa.

Here, we conduct a comprehensive survey of SHB infestation levels of African honey bee colonies in both forest and savannah with a range of temperatures and rainfall regimes to further investigate the impact of environmental factors. Based on data so far, we expect higher infestation levels in warmer and more humid areas as well as higher infestations in forests compared to savannah.

\section{METHODS}

\subsection{Survey}

In Nigeria, SHB infestation levels were estimated in June and July 2016 (early local wet season) in 82 local queenright honey bee colonies, A. m. adansonii, at 26 apiaries, thereby covering 14 states in both forest and savannah ecosystems (Figure 1) with a wide range of annual temperatures and rainfall. Introductions of European honey bee subspecies into Africa have repeatedly failed (Hepburn and Radloff 1998). There is also no long-range migratory beekeeping in Nigeria as in other countries (e.g., USA) and no major import of bees from the neighboring countries. Therefore, it appears safe to assume that the local studied bees were indeed $A$. $m$. adansonii even without any morphometric and/ or molecular work. Earlier definitions and open access Google satellite maps were used to classify the apiary locations as being located in forest 


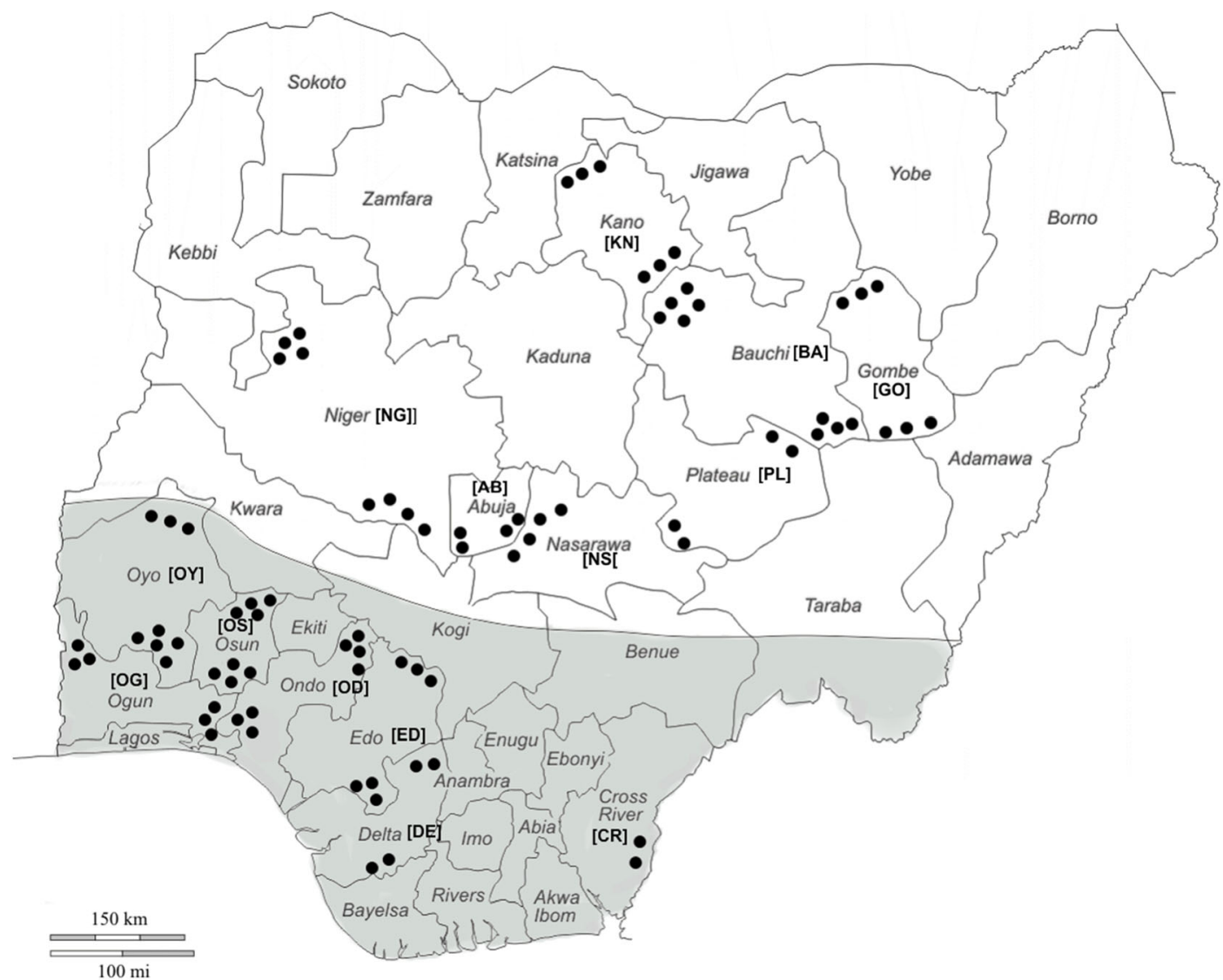

Figure 1. Political map of Nigeria showing the states, ecosystems (gray area = forest, white area = savannah), and sampled colonies $(=$ circles).

or savannah, respectively (MacGregor 1937; Hepburn and Radloff 1998; https://www.google. ch/maps/place/Nigeria/@9.8070716,8.3800163 ,221156m/data $=! 3 \mathrm{~m} 1$ ! $1 \mathrm{e} 3 ! 4 \mathrm{~m} 5 ! 3 \mathrm{~m} 4$ ! $1 \mathrm{~s} 0 \times 104 \mathrm{e} 0$ baf7da48d0d:0x99a 8 fe 4168 c50 bc 8 ! $8 \mathrm{~m} 2$ !3d9.081999!4d8.675277).

All surveyed colonies were housed in standard Langstroth hives and were visually screened for SHBs in a standardized fashion (Neumann et al. 2013) during early mornings by the same person (A.K.L.). All spotted adult SHBs were collected using aspirators (Neumann et al. 2013) from only the bottom boards to limit disturbance of the colonies. Since $\sim 50 \%$ of the adult SHBs in infested hives can be found on the bottom boards (Neumann and Elzen 2004), this method provides reasonable estimates of the overall infestation levels. Geographical coordinates of the sampling locations were recorded using Qmini M series Data collectors (HiTarget, China), and respective local temperature and precipitation data were obtained from the Nigeria Meteorological Center.

\subsection{Statistical analyses}

Data were tested for normality using Kolmogorov-Smirnov and Shapiro-Wilk tests. Since the data were not normally distributed, the SHB infestation levels in colonies were analyzed for differences between the two ecosystems and the 7 states in each ecosystem using a KruskalWallis ANOVA (level of significance: $\alpha=0.05$ ), while analyses for relationship in the number of beetles, temperature, and rainfall between the different ecosystems were performed using bivariate correlations with Kendall's tau-b correlation 
coefficient $\left(\tau_{\mathrm{b}}\right)$. All statistical tests were run in a General Linear Model (GLM) using the statistical software package SPSS version 20.

\section{RESULTS}

\subsection{Ecosystems and infestation levels}

A total of 70 out of 82 colonies were infested with adult SHBs (85.36\%; Figure 2). A significant difference in SHB infestation levels was found between the forest and savannah ecosystems (forest, median $=60$, interquartile range $(\mathrm{IQR})=$ 117.5-46 =71.5; savannah, median $=51$ and $\mathrm{IQR}=80.5-21=59.5 ; \chi^{2}(1)=4.288, p=$ $0.038)$. However, there were no significant differences in SHB infestation levels among the seven states sampled in the forest $\left(\chi^{2}(6)=8.142, p=\right.$ 0.228 ) and similarly for the seven states sampled in the savannah ecosystem $\left(\chi^{2}(6)=7.935, p=\right.$ 0.243 ) at Kruskal-Wallis CL level $=95 \%$.

\subsection{Temperature and infestation levels}

For overall colonies in both ecosystems (forest and savannah), the relationship between temperature and SHB infestation levels was positive, but not statistically significant $\left(\tau_{\mathrm{b}}=0.113, p=0.078\right.$, $\mathrm{CL}=95 \%$; Figure 3 ). Such a positive, but not statistically significant, correlation was also the case between temperature and SHB infestation levels in individual colonies within the same apiaries in the seven states for each of the forest and savannah ecosystems (forest $\left(\tau_{\mathrm{b}}=0.057, p=\right.$ $0.312)$ and savannah $\left(\tau_{\mathrm{b}}=0.095, p=0.209, \mathrm{CL}=\right.$ $95 \%)$ ).

\subsection{Rainfall and infestation levels}

For the relationship between rainfall and overall SHB infestation levels for all the colonies in the ecosystems, forest and savannah showed a positive correlation, which was statistically

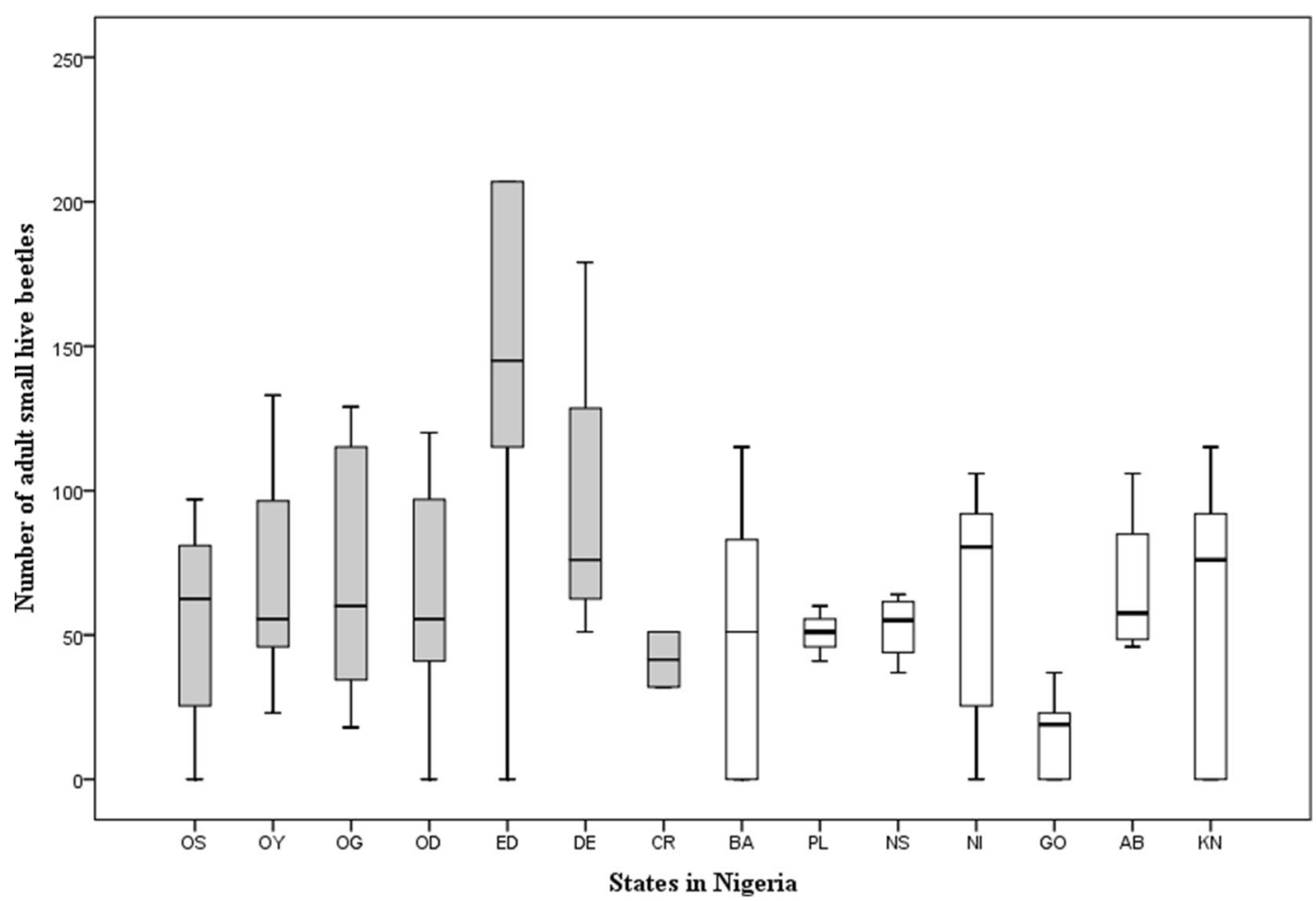

Figure 2. Infestation levels per colony of adult small hive beetles in A. $m$. adansonii colonies in the sampled regions of Nigeria. Medians, quartiles, and ranges are shown (gray bars = forest, white bars = savannah; please refer to Figure 1 for the full state names). 


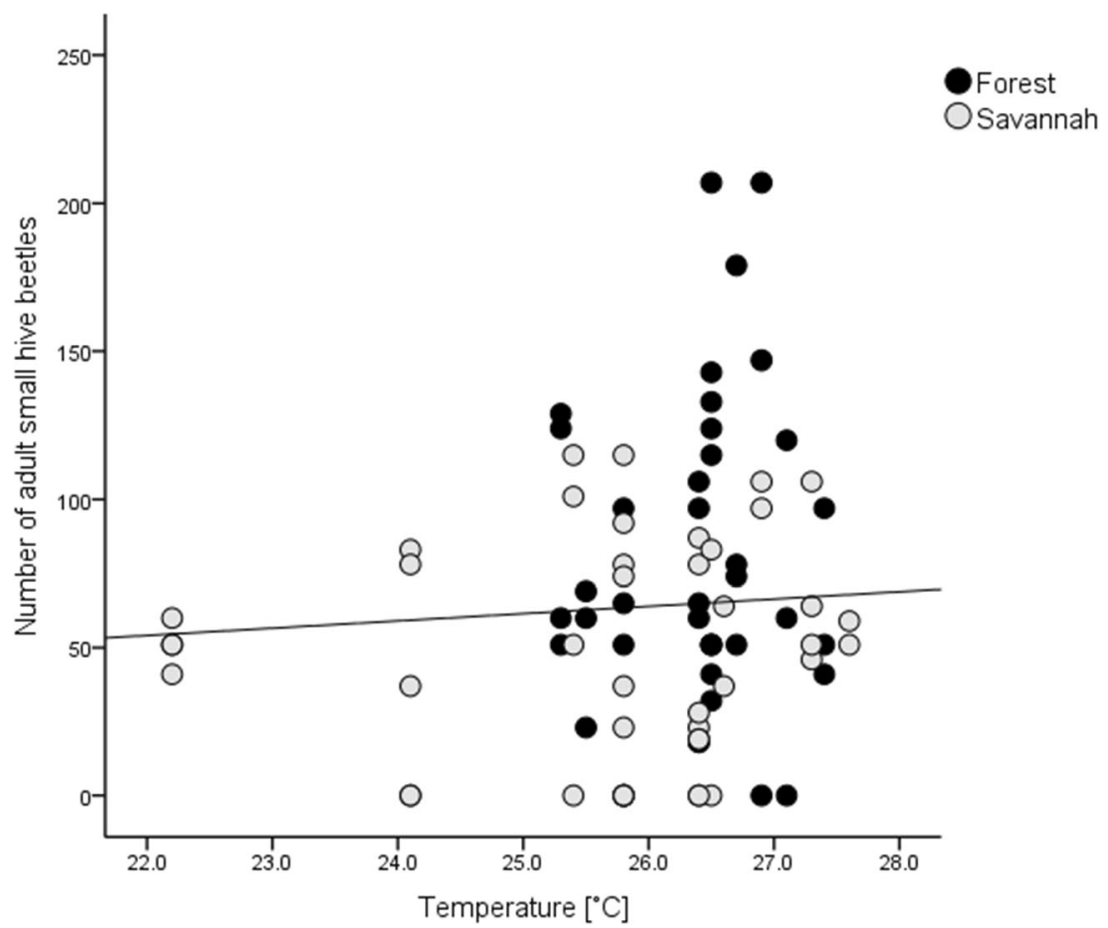

Figure 3. Local temperature and infestation levels of $A$. $m$. adansonii colonies with adult small hive beetles per colony. No significant correlation was found (Kendall's tau_b $\tau_{\mathrm{b}}=0.113, p=0.078,>0.05$ ).

significant $\left(\tau_{\mathrm{b}}=0.141, p=0.035, \mathrm{CL}=95 \%\right.$; Figure 4). However, the relationship between rainfall and SHB infestation levels in individual colonies within the same apiary in the seven states in each of the forest and savannah ecosystems showed no significant correlation for either forest $\left(\tau_{\mathrm{b}}=0.057, p=0.291\right)$ or savannah $\left(\tau_{\mathrm{b}}=0.053\right.$, $p=0.321, \mathrm{CL}=95 \%)$.

\section{DISCUSSION}

Our data show that SHB infestations of African honey bee (A. m. adansonii) colonies are common in both forest and savannah ecosystems of Nigeria. The results also indicate a substantial impact of environmental factors on these SHB infestation levels. Infestation levels were higher in forests compared to savannah, and a positive correlation was observed between local rainfall patterns and infestation levels. Most likely, higher soil moisture in forests due to higher precipitation promotes local SHB pupation and consequently infestation levels of honey bee colonies.
Data collection at each apiary (e.g., via data loggers) might have provided even more robust estimates of the investigated environmental parameters. However, this was clearly not feasible due to the rather difficult logistics in the diverse habitats across Nigeria. Temperature had no significant effect in this study, probably because the range of tested regimes lays well within the optimum for SHB pupation (Neumann et al. 2001; Mürrle and Neumann 2004; de Guzman and Frake 2007; de Guzman et al. 2009; de Guzman et al. 2010; reviewed by Neumann et al. 2016). Indeed, at continental scales, temperature can play a key role, e.g., limiting the northern distribution limit of the SHB in Canada (Giovenazzo and Bernier 2015; Neumann et al. 2016).

Local SHB infestation levels did overall positively correlate with rainfall, probably due to the key role it plays in regulating soil humidity and the respective impact on SHB pupation (Ellis et al. 2004; Meikle and Diaz 2012). However, there might be differences with respect to the ecosystem. Indeed, rainfall did significantly 


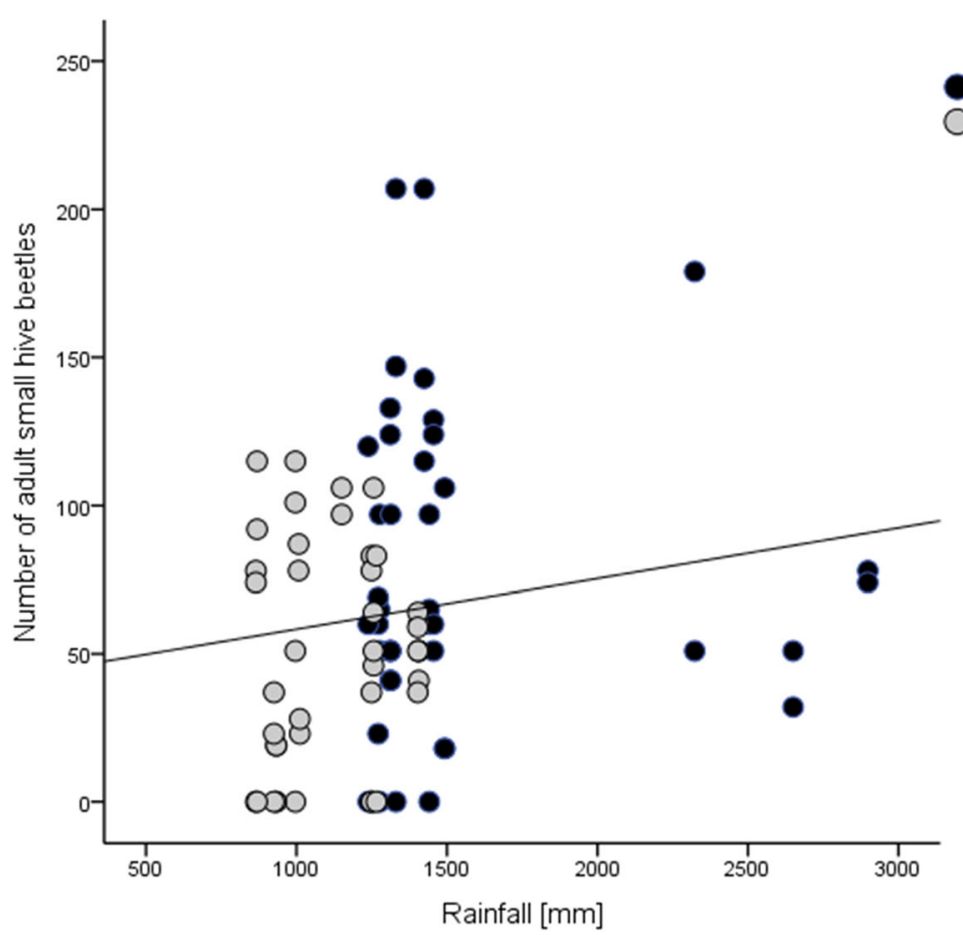

Figure 4. Local rainfall and infestation levels of A. $m$. adansonii colonies with adult small hive beetles. A significant positive correlation was found (Kendall's tau_b $\tau_{\mathrm{b}}=0.141, p=0.035,<0.05$ ).

correlate with SHB infestation levels in the forest; this was not the case for the savannah. What are the possible reasons for this difference? It seems obvious that rainfall is a key factor determining soil moisture levels. While there is ample high rainfall in the forest zone in Southern Nigeria, which contributes to high soil moisture content, the savannah of Nigeria is characterized by low and erratic rainfall (Afolabi et al. 2009). Our results show accordingly that SHB infestation levels were significantly higher in the forests compared to the savannah. Other factors may also come into play. It is known that adult SHBs tend to prefer shaded colonies over sun-exposed ones (Arbogast et al. 2007, 2009; but see Ellis and Delaplane 2006). In the forest, the trees form complete canopies (Nardkarni 1994) while in the savannah, the trees are widely spaced (Buba 2015). Furthermore, on the forest floor, fallen leaves and other decaying organic material and the fauna, e.g., abundant other beetles
(Nardkarni 1994), are likely to improve soil type, thereby further contributing to SHB pupation success (Ellis et al. 2004; reviewed by Neumann et al. 2016). Moreover, wild and feral bee colonies (Hepburn and Radloff 1998), alternative hosts (i.e., stingless bee colonies; Wade 2012, cf. Neumann et al. 2016), and/or alternative food sources (i.e., on fruits; Buchholz et al. 2008) that provide additional reproductive opportunities may be more abundant in the forests compared to the savannah. In conclusion, there are several possible reasons why forests can display higher SHB infestations levels. Since the significant positive effect of rainfall was only observed in the forest, this suggests that those factors impacting SHB pupation are more likely to contribute.

It is evident that rainfall and forest alone cannot explain SHB population dynamics. Even though few other data are available, there seems to be considerable variation in the correlations between SHB infestation levels and 
environmental factors. In Louisiana (USA), SHB abundance was significantly correlated with the proportion of hot days, but not with the proportions of cool, dry, or humid days, or the percentage of days with rainfall (de Guzman et al. 2010). On the other hand, trap captures in Kenya indicated that SHB, present in honey bee colonies in low numbers all year round, is most abundant during the rainy season, with over $80 \%$ trapped during this period (Torto et al. 2010). Likewise, traps installed in Kenya in front of infested hives over an entire year showed that more wandering larvae left infested colonies during the "kusi monsoon" (Arbogast et al. 2012). In contrast, both adult and larval SHB were more often found inside colonies during the dry season in Nigeria compared to the wet season (Lawal and Banjo 2008). All these observations taken together strongly suggest that many more factors are involved to explain local SHB infestation levels, i.e., abundance of wild/feral honey bee colonies, alternative hosts, natural enemies, sanitation at apicultural facilities, etc. (Spiewok et al. 2007; reviewed by Neumann et al. 2016). Our observations of differences in SHB populations between forest and savannah as well as the positive correlation with precipitation support the view that environmental factors can be important drivers of local SHB infestation levels.

\section{CONCLUSION}

Under the temperature conditions of the study region, precipitation and a forest cover appear to impact SHB infestation levels of honey bee colonies.

\section{ACKNOWLEDGEMENTS}

Appreciation is addressed to all the beekeepers. Dr. Usman Dukku, Abubakar Tafawa Balewa University, Bauchi, Nigeria; Adekola Popoola, Federal College of Forestry, Jericho, Ibadan, Nigeria; and Femi Oguntuyi are acknowledged for their technical support during the field work.

\section{AUTHOR CONTRIBUTIONS}

$\mathrm{AK}$ and $\mathrm{PN}$ conceived this research and designed the experiments. AK performed the data analyses. AK performed the experiments and analysis. AK and PN wrote the paper and participated in the revisions of it. All authors read and approved the final manuscript.

\section{FUNDING INFORMATION}

Financial support was granted to $\mathrm{PN}$ and $\mathrm{AK}$ by the Vinetum foundation.

Les faibles niveaux d'infestation des colonies d'abeilles mellifères par les coléoptères des ruches sont en corrélation avec les précipitations et le couvert forestier

Aethina tumida / Apis mellifera adansonii / écosystème / abeille mellifère / parasite / petit coléoptère des ruches

Der Befall von Honigbienenvölkern mit dem Kleinen Beutenkäfer korreliert mit Niederschlägen und dem Umfang der Bewaldung.

Aethina tumida / Apis mellifera adansonii / Ökosystem / Honigbienen / Parasit / Kleiner Beutenkäfer

\section{REFERENCES}

Afolabi, L.A., Akinyemi, G.O., Aderibigbe, A.T.O. (2009) Effects of rainfall patterns on soil moisture, soil temperature and plant growth in humid forest zone Nigeria. Am. - Euro. J. Sust. Agriculture 3 (3), 413-417.

Arbogast, R.T., Torto, B., Van Engelsdorp, D., Teal, P.E. (2007) An effective trap and bait combination for monitoring the small hive beetle, Aethina tumida (Coleoptera : Nitidulidae). Florida Entomol. 90 (2), 404406.

Arbogast, R.T., Torto, B., Teal, P.E. (2009) Monitoring the small hive beetle Aethina tumida (Coleoptera: Nitidulidae ) with baited flight traps: effect of distance from bee hives and shade on the numbers of beetles captured. Florida Entomol. 92 (1), 165-166.

Arbogast, R.T., Torto, B., Willms, S., Fombong, A.T., Duehl, A., Teal, P.E. (2012) Estimating reproductive success of Aethina tumida (Coleoptera: Nitidulidae) in honey bee colonies by trapping emigrating larvae. Environ Entomol. 41 (1), 152-158.

Buba, T. (2015) Impact of different types of land use on pattern of herbaceous plant community in the Nigerian Northern Guinea Savanna. J. Agric. Ecol. Res. Intern. 4(4), 151-165. 
Buchholz, S., Schäfer, M.O., Spiewok, S., Pettis, J.S., Duncan, M., Ritter, W., Spooner-Hart, R., Neumann, P. (2008) Alternative food sources of Aethina tumida (Coleoptera: Nitidulidae). J. Apic. Res. 47(3), 201208.

Cervancia, C.R., de Guzman, L., Polintan, E.A., Dupo, A.L-.D., Locsin, A.A. (2016) Current status of small hive beetle infestation in the Philippines. J. Apic. Res. 55 (1), 74-77. https://doi.org/10.1080 /00218839.2016.1194053

Dawson, W., Dietmar, M., van Kleunen, M, Holger, K., Jan, P., Petr, P., Patrick, W., Marten, W., Bernd, L., Tim, M. B., Ellie, E. D., Phillip, C., Sally, L. S., Evan, P. E., Benoit, G., César, C., Hanno, S., Pablo, G., Wolfgang, N., Emili, G., Christine, C., Nicholas, E. M., Pam, F., Carsten, M., Franz, E. (2017). Global hotspots and correlates of alien species richness across taxonomic groups. Nature Ecol. Evol., https://doi. org/10.1038/s41559-017-0186.

de Guzman, L.I., Frake, A.M. (2007) Temperature affects Aethina tumida (Coleoptera: Nitidulidae) development. J. Apic. Res. incorp Bee World 6, 88-93.

de Guzman, L.I., Prudente, J.A., Rinderer, T.E., Frake, A.M., Tubbs, H. (2009) Population of small hive beetles (Aethina tumida Murray) in two apiaries having different soil textures in Mississippi. Sci. Bee Culture 1, 4-8.

Ellis, J.D. (2005) Reviewing the confinement of small hive beetles (Aethina tumida) by western honey bees (Apis mellifera). Bee World 86(3): 56-62. https://doi. org/10.1080/0005772X.2005.11417312.

Ellis, J.D., Delaplane, K.S. (2006) The effects of habitat type, ApilifeVAR ${ }^{\mathrm{TM}}$, and screened bottom boards on small hive beetle (Aethina tumida) entry into honeybee (Apis mellifera) colonies. Am. Bee J. 146, 537539.

Ellis, J.D., Neumann, P., Hepburn, H.R., Elzen, P.J. (2002) Longevity and reproductive success of Aethina tumida (Coleoptera: Nitidulidae) fed different natural diets. Journal of Economic Entomology 95(5): 902-907. https://doi.org/10.1603/0022-0493-95.5.902.

Ellis, J.D., Hepburn, R., Luckman, P., Elzen, P.J. (2004) Effects of soil type, moisture, and density on pupation success of Aethina tumida (Coleoptera: Nitidulidae). Environ. Entomol. 33, 794-798.

Giovenazzo, P., Bernier, M. (2015) Situation du petit coléoptère de la ruche au Québec, L'Abeille 37(2), 8-9.

de Guzman, L.I., Frake, A.M., Rinderer, T.E. (2010) Seasonal population dynamics of small hive beetles, Aethina tumida Murray, in the south-eastern USA. J Apic Res incorp Bee World 49(2), 186-191.

Hepburn, H.R., Radloff, S.E. (1998) Honeybees of Africa. Springer Verlag, Berlin.

Lawal, O.A., Banjo, A.D. (2008) Seasonal variations of pests and parasites associated with honeybees (Apis mellifera adansonii) in Southwestern Nigeria. Acad. J. Entomol. 1 (1), 01-06.
Lundie, A.E. (1940) The small hive beetle, Aethina tumida . Sci. Bull 220, Union of South Africa, Department of Agriculture and Forestry.

MacGregor, W.D. (1937) Forest types and succession in Nigeria. Empire Forestry J. 16 (2), 234-242.

Meikle, W.G., Diaz, R. (2012) Factors affecting pupation success of the small hive beetle, Aethina tumida. J. Ins. Sci. 12 (118), 1-9.

Mitchell, C.E., Power, A.G. (2003) Release of invasive plants from fungal and viral pathogens. Nature 421, 625-627).

Mürrle, T., Neumann, P. (2004) Mass production of small hive beetles (Aethina tumida, Coleoptera: Nitidulidae ). J. Apic. Res. 43 (2), 144-145.

Mutinelli, F., Federico, G., Carlin, S., Montarsi, F., \& Audisio, P. (2015). Preliminary investigation on other Nitidulidae beetles species occurring on rotten fruit in Reggio Calabria province (south-western Italy) infested with small hive beetle (Aethina tumida). J. Apic. Res. 54, 233-235. https://doi.org/10.1080 /00218839.2016.1142733

Nardkarni, N.M. (1994) Diversity of species and interactions in the upper tree canopy of forest ecosystems. Am. Zool. 34, 70-78.

Nentwig, W. (2007) Biological Invasions-Why it Matters. Springer Verlag, Berlin Heidelberg.

Neumann, P. (2017) Small hive beetle in Italy: what can we expect in the future? In: N. L. Carreck (Ed.) The small hive beetle - a growing problem in the $21^{\text {st }}$ century. International Bee Research Association, Bristol, U.K., pp. 33-40, ISBN : 978-0-86098-278-4.

Neumann, P., Elzen, P.J. (2004) The biology of the small hive beetle (Aethina tumida, Coleoptera: Nitidulidae): gaps in our knowledge of an invasive species. Apidologie 35, 229-247.

Neumann, P., Pirk, C.W.W., Hepburn, H.R., Elzen, P.J., Baxter, J.R. (2001) Laboratory rearing of small hive beetles Aethina tumida (Coleoptera: Nitidulidae). J. Apic. Res. 40, 111-112.

Neumann, P., Hoffmann, D., Duncan, M., Spooner-Hart, R., Pettis, J.S. (2012) Long-range dispersal of small hive beetles. J. Apic. Res. 51 (2), 214-215.

Neumann, P., Evans, J.D., Pettis, J.S., Pirk, C.W.W., Schäfer, M.O., Tanner, G., Ellis, J. D. (2013) Standard methods for small hive beetle research. J. Apic. Res. 52, 4. https://doi.org/10.3896/IBRA.1.52.4.19.

Neumann, P., Naef, J., Crailsheim, K., Crewe, R.M., Pirk, C.W.W. (2015) Hit-and-run trophallaxis of small hive beetles. Ecol. Evol. 11/2015, https://doi.org/10.1002 /ece3.1806.

Neumann, P., Pettis, J.S., Schäfer, M.O. (2016) Quo vadis Aethina tumida? Biology and control of small hive beetles. Apidologie 47: 427. https://doi.org/10.1007 /s13592-016-0426-X

Pirk, C.W.W., Neumann, P. (2013) Small hive beetles are facultative predators of adult honey bees. J. Insect Behav. 26, 796-803. 
Rosenkranz, P., Aumeier, P., Ziegelmann, B. (2010) Biology and control of Varroa destructor. J. Inv. Pathol. 103, 96-119.

Spiewok, S., Neumann, P. (2006) Cryptic low-level reproduction of small hive beetles in honey bee colonies. J. Apic. Res. 45, 47-48.

Spiewok, S., Pettis, J.S., Duncan, M., Spooner-Hart, R., Westervelt, D., Neumann, P. (2007) Small hive beetle, Aethina tumida, populations I: infestation levels of honeybee colonies, apiaries and regions. Apidologie $38(6), 595-605$.

Torchin, M.E., Lafferty, K.D., McKenzie, V.J., Kuris, A.M. (2003) Introduced species and their missing parasites. Nature 421, 628-630.
Torto, B., Fombong, A.T., Arbogast, R.T., Teal, P.E. (2010) Monitoring Aethina tumida (Coleoptera: Nitidulidae) with baited bottom board traps: occurrence and seasonal abundance in honey bee colonies in Kenya. Environ. Entomol. 39, 1731-1736.

Wade, R. (2012) Keeping out small hive beetles, Aussie Bee Online Article 18, [online] http://www.aussiebee. com.au/aussiebeeonline018.pdf.

Willcox, B.K., Howlett, B.G., Neumann, P. (2017) Absence of small hive beetles from flowering plants. J. Apic. Res. 56 : 643-645. DOI: https://doi.org/10.1080 /00218839.2017.1355347. 